altogether destitute of elongated hairs on that part, the antennæ however are widely different. I do not remember to have met with the third sp. of $\nexists$. you mention; but your description of the Bombyx agrees perfectly with B. Jo of authors, yet, I cannot suppose that Profess'r Peck was unacquainted w. that insect which is so common in nasure \& familiar in the books; if indeed it is not that species it is without doubt new.

Fabr. did not live to publish his Systema Glossatorum, but the work was left in manuscript, \& was finally publ'd, I think, by Illiger, but I have never met with it, \& have therefore, with you, to rely entirely on the Edinb. Encyc. for his genera. Coquebert in his Decades proposes to illustrate the works of Fabr. by figures; his figures are good \& represent the genera as they stood at that time, but so many divisions have been since made that the book might lead to error if implicitly relied upon. I have seen but one copy of this work, $\&$ doubt much if it can be purchased in this country. I have no idea of the price in Europe. It is a folio vol. \& contains if I remember rightly $3^{\circ}$ plates.

The number of the Journal A. N. S. containing Mr. Worth's obs's on the Peach tree destroyer will be published about Tuesday next. I thank you for mentioning the name of the work in wh. Prof. Peck published his desc's, we have the Jour. Mass. Agric. Soc. here \& I can refer to them.

To communicate any information I may possess to those who are in pursuit of knowledge in Zoology, affords me, I assure you, much gratification, I therefore hope that you will not scruple to command me freely, though on the other hand such are the nature of my avocations I cannot promise always to answer promptly.

\title{
SOME OF THE EARLY STAGES OF ZERENE CATENARIA.
}

BY SAMUEL H. SCUDDER.

ON September 24, I859, I raised a female of this species, and kept her in confinement. On the third day she began to lay eggs and in the next two or three days laid 259 of them. Two years afterwards I placed a similar female, as soon as born, alone in a large box with a sprig of sweet fern (Comptonia asplenifolia), but her eggs were in all cases dropped loose in the box. The eggs are about $0.75 \mathrm{~mm}$. in height, ovato-spheroidal, truncate at base, very minutely punctured, and of a somewhat pale pea-green color. None hatched.

The caterpillar is very common on sweet fern, and is said by Packard to feed upon Carex pennyslvanica, and also on "blackberry, woodwax, wild indigo, etc." It lives solitarily, though many are often found upon a single plant, and when full grown may be frequently seen extended in a straight rigid 
position upon a twig, supported only by its two pairs of prolegs, the body at an angle of about forty-five degrees with the terminal segments. In this position it may remain a long time.

Its general color is a greenish lemon yellow or straw color. The body is largest at the seventh abdominal segment, and tapers very regularly and gently in each direction, the head being scarcely broader than the first thoracic segment. 'The head has the mouth parts white, a transverse series of three black dots on the frontal triangle, and on each lobe of the head a series of four similar dots arranged in a quadrilateral. The body is marked by several longitudinal series of very delicate reddish brown lines, two on either side above and three on either side below the spiracles, those above being apparently latero-dorsal and infralateral, the latter the finer; the first thoracic segment bears a rounded dorsal shield with four black dots arranged in a quadrilateral, and on either side of each thoracic segment is a single, on that of each abdominal segment a pair, of short, transverse, black spots (one in front of and one behind the spiracle) the lower ends of which are on the stigmatal line; each of the legs has a pair of black dots and each of the prolegs two vertical series of similar dots, the hinder series of the hindmost pair forming a triangular cluster, its apex downward; the last segment has an arcuate series of four black dots, opening forward, besides a cluster of smaller ones at the extreme posterior margin, and the penultimate a transverse series of four dots next the posterior edge, two subdorsal and two stigmatal; spiracles marked by a black dot encircled with milky white. Length $45 \mathrm{~mm}$.

The cocoon is an ovate open-meshed net about $25 \mathrm{~mm}$. long by $S \mathrm{~mm}$. in greatest breadth, made of shining yellow silk; the meshes are so open that the caterpillar in making the cocoon can thrust its head through any of them. yet on completion the cocoon is rigid and yields to handling less than many compact cocoons, so stiff are the threads. It is also strengthened by the guys which attach it to the surrounding foliage. When completed, it is much shorter than the enclosed caterpillar, which is obliged to lie in a cork-screw-like position until his change occurs, and then by his contortions he contrives to eject the cast skin through the meshes of the cocoon.

The chrysalis is of a white color, though a pale pea-green tint suffuses the thorax and appendages, especially on the ventral side, and the abdominal segments are edged posteriorly with lemon yellow, except the last two which are black. There are also some other distinctive marks: the head is covered with short curved irregular lines and dots, and has a few yellow spots on top; the ocellar riband is black; all the incisures of the appendages are marked with black, and the wing veins are indicated by ragged black lines now and then interrupted; there is a dorsal yellow streak on the abdomen which is bounded by short black lines and dots; cremaster yellow except the reddish testaceous tip. Length $22 \mathrm{~mm}$.; breadth $4.5 \mathrm{~mm}$.

An inky tinge begins to suffuse the body about three days before emerging; it first affects the dorsum of the thorax, then it extends to the head and rest of the thorax except the wings and to the ventral portion of the abdominal segments just succeeding the wingtips, and finally to nearly the whole body. I once chanced to observe a moth while emerging; it had thrust its body forward out of the chrysalis skin 
so as to touch the cocoon. I saw it force its way out through one of the meshes, which it did in a few seconds by a series of starts, pushing itself with its legs and opening and contracting its limp wings; it made use of any limb as soon as it was free from its encasements, and as soon as it was out of the cocoon it took up a position where its wings could properly hang and expand.

Most of the imagos bred by me came out in the third week of September; one was in chrysalis from August 23 to September 24, or thirty-two days. As, according to Packard, there is but one brood a year and eggs are laid very soon after hatching, it is probable that winter is passed in the egg state. Packard figures the caterpillar, but not (as he says) the pupa, in his Monograph of the Phalaenidae. (From notes taken in 1859 and 1861 .)

\title{
A LIST OF THE BOMBYCES FOUND IN THE ELECTRIC LIGHT GLOBES AT POUGHKEEPSIE, N. Y.
}

\author{
BY HARRISON G. DYAR, NEW YORK.
}

During the summer of 1890 I made nine visits to the electric lamps of Poughkeepsie and the following list shows the number of Bombyces that they contained at each visit, with totals. I have included also the names of all Bombyces that I have found in western Dutchess County even though not found in the lamps in 1890 . The numbers will give a fair idea of the relative abundance of the different species. To my surprise I found Halesidota tessellaris the most abundant though, judging from the larvae, it was no more common than usual, while Clisiocampa americana, which was second in abundance, was unusually common, doing much injury to the wild cherry and apple trees.

I visited about one-third of the electric lights in Poughkeepsie and took al- together 7874 specimens. The list contains II4 species. The seven most numerous species, those comprising one per cent or over of the total number, were the following:-

Halesidota tessellaris Sm. Abb. 34

Clisiocampa americana Harr. $\quad 31$

Hyphantria var. textor Harr. $\quad$ I.6

Spilosoma virginica Fabr. I

Clisiocampa disstria Hübn. I

Hyperchiria io Fabr. I

Pyrrharctia isabella Sm. Abb. I

All the rest together ( 88 species) I5

I was greatly assisted in making the collections here recorded by the kindness of Mr. J. H. Van Norstrand of Poughkeepsie who takes care of the electric lights I visited. 

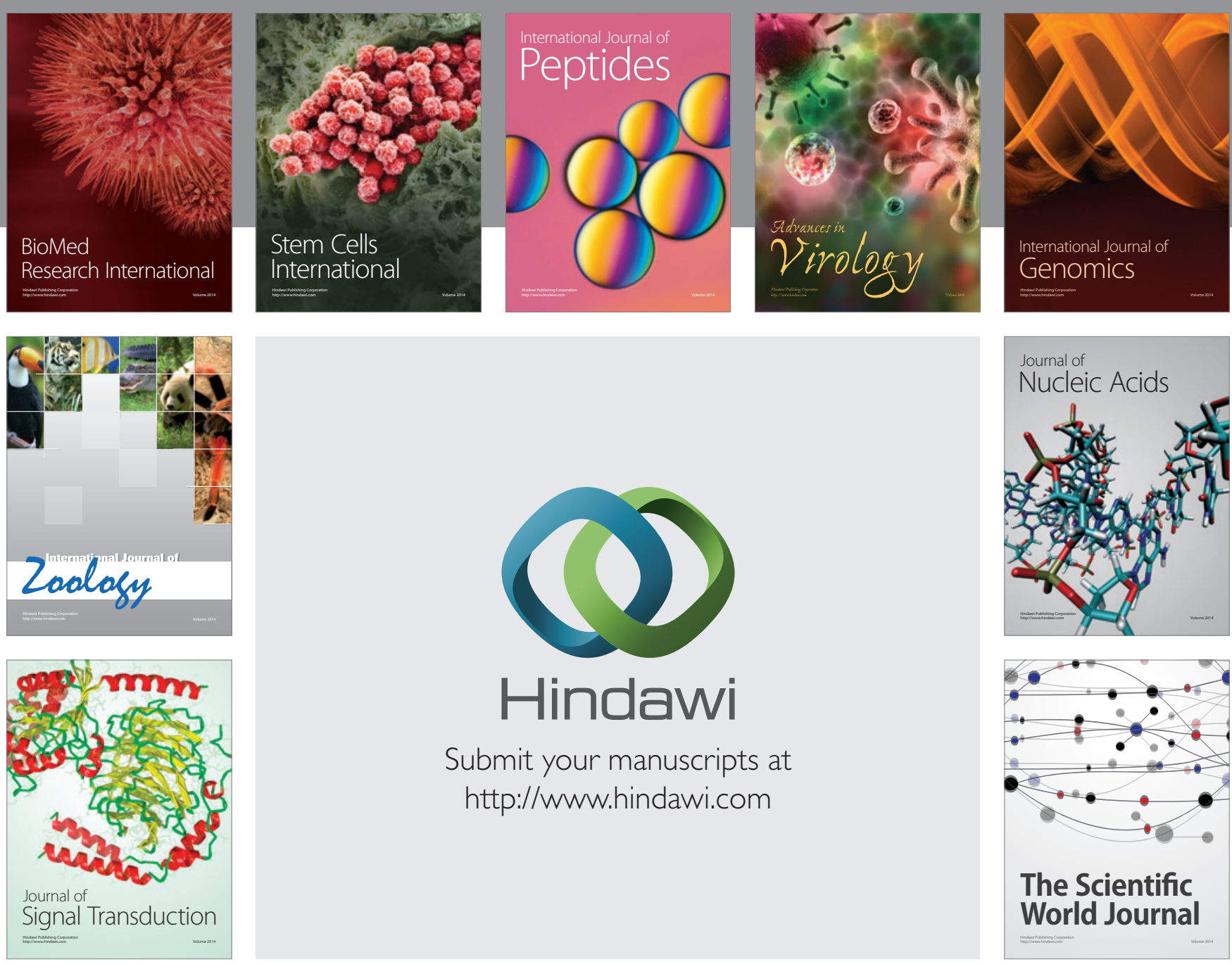

Submit your manuscripts at

http://www.hindawi.com
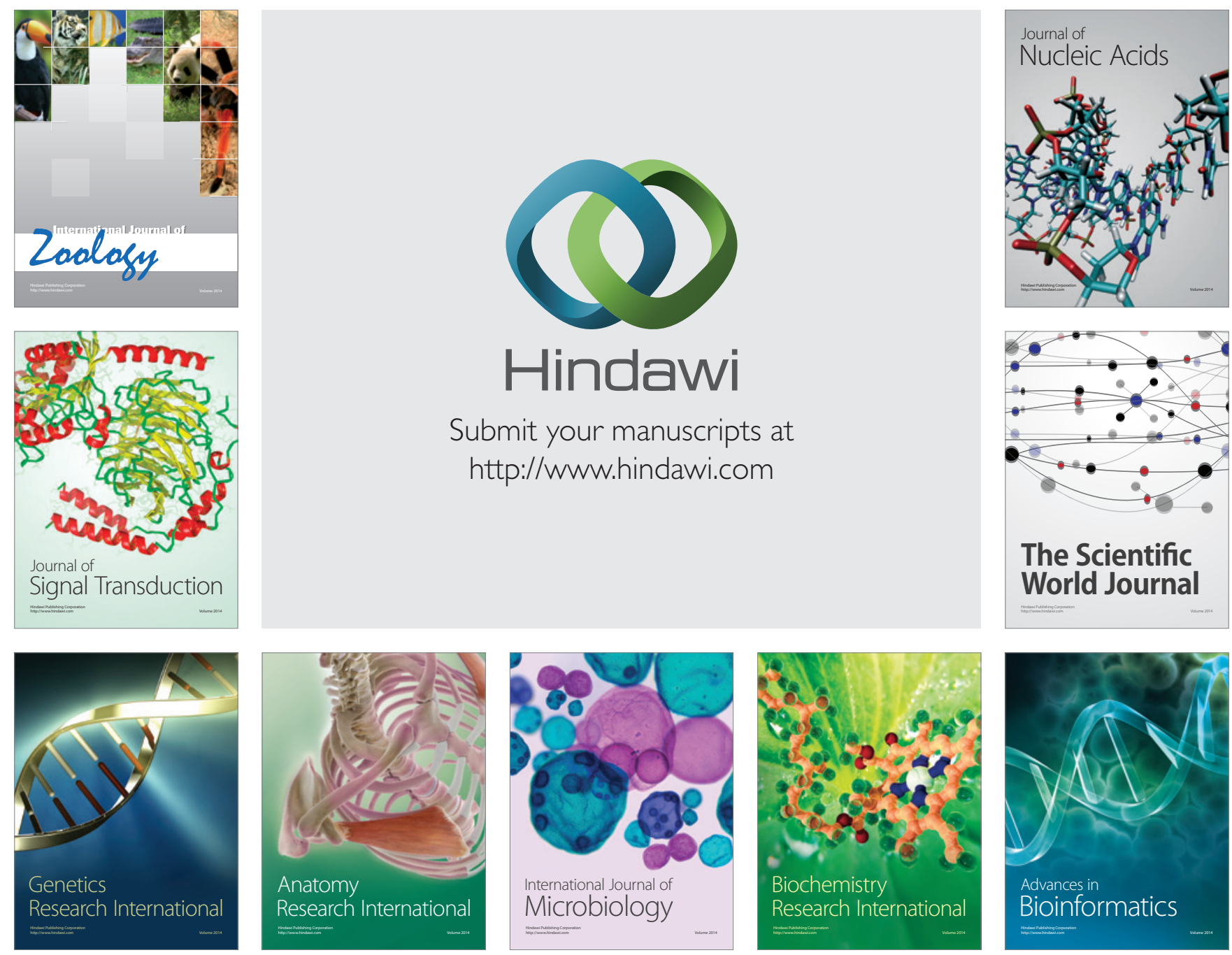

The Scientific World Journal
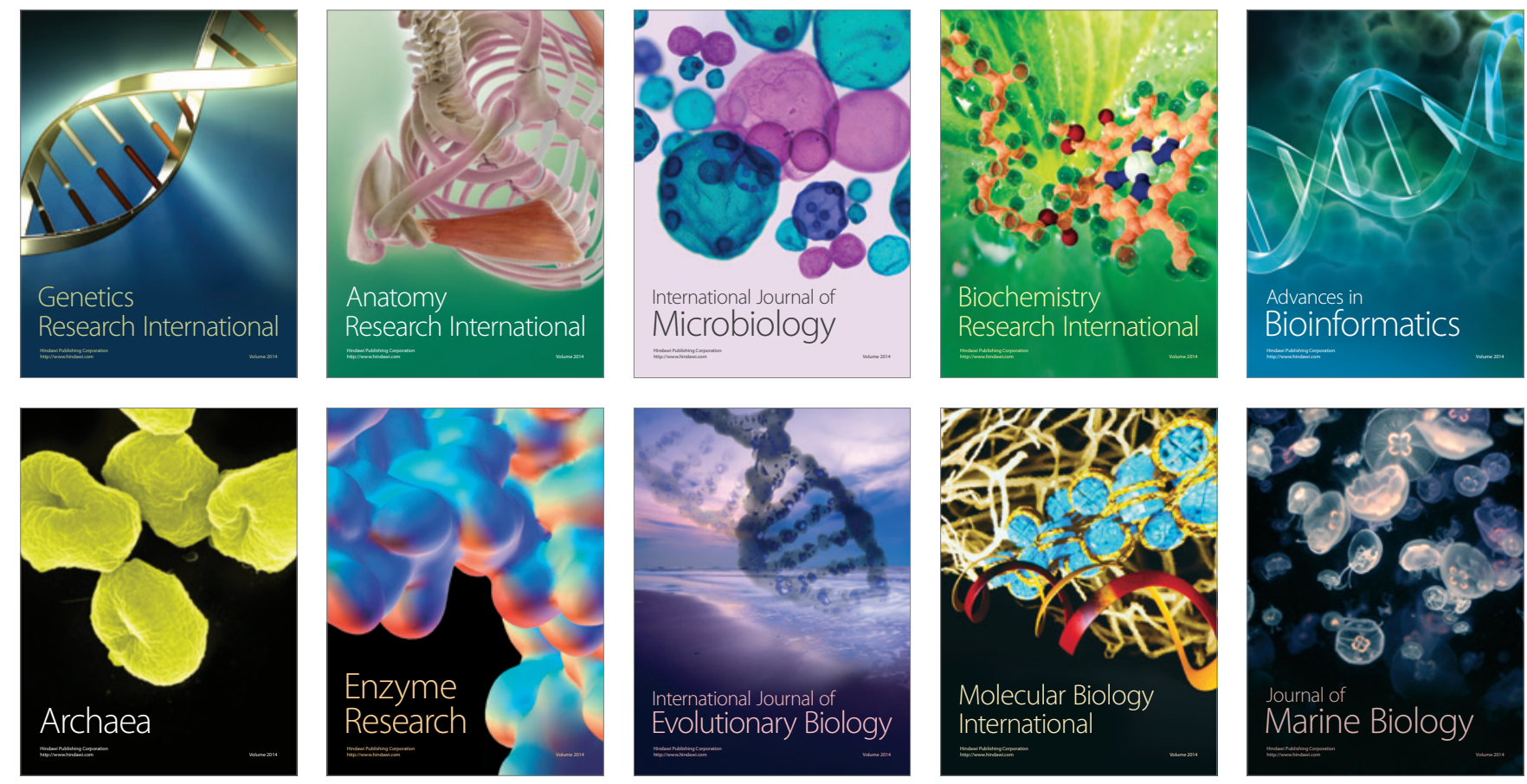